\title{
Study of Converted-Wave Modeling: AVO Application for Shallow Gas Models
}

\author{
Studi Pemodelan Converted-Wave: Aplikasi AVO untuk Model Gas Dangkal
}

\author{
${\text { Natashia Christy } \text { Viony }^{1 *} \text {, Wahyu Triyoso }}^{2}$ \\ ${ }^{1}$ Teknik Geofisika, Fakultas Teknik Pertambangan dan Perminyakan, Institut Teknologi Bandung, \\ Jalan Ganesa No 10, Bandung, 40132 \\ 2 Kelompok Keahlian Geofisika Global, Fakultas Teknik Pertambangan dan Perminyakan, Institut Teknologi Bandung, \\ Jalan Ganesa No 10, Bandung, 40132 \\ *Email: natashiacv@gmail.com
}

Submit: 16 Juni 2018; Revised: 4 September 2018; Accepted: 10 September 2018

\begin{abstract}
The application of converted-wave seismic method in hydrocarbon exploration has increased significantly. Since the conventional seismic ceases to provide an adequate result in complex geology area and it provides an ambiguous brightspot response. The main principle is that an incident $P$-wave produces reflected and converted $P$ and $S V$ wave when the downgoing P-wave impinges on an interface. Converted-wave seismic uses the multicomponent receiver that records both of vertical component and horizontal component. The vertical component is assumed to correspond to the compressional PP wave and the horizontal correspond to the PS converted-wave. In this research, a synthetic model with the shallow gas and the salt dome below are constructed. The purpose of this study is to analyze the brightspot due to the presence of shallow gas and its effect to the quality of PP and PS wave reflection below the gas zone. To achieve the goal, both vertical and horizontal seismic data processing are performed. In horizontal data processing, the best gamma function $\left(V_{p} / V_{s}\right)$ value is estimated to produce the better and reliable image. The result shows that the brightspot response in conventional data doesn't exist in converted-wave data and the imaging below the gas zone in converted-wave data is better than the conventional due to the attenuation and diffraction effect that caused by gas column. Processing is followed by AVO analysis to compare the $A V O$ response of $P P$ and $P S$ data in characterizing gas reservoir. Both PP and PS AVO curve shows the consistency with synthetic AVO from well data. Gas reservoir is a class 1 AVO anomaly with positive intercept and negative gradient on PP data. However, PS AVO curve does not refer any anomaly. It is because $S$-wave is not sensitive to the existence of rock saturant.
\end{abstract}

Keywords: $A V O$, converted-wave, salt dome, shallow gas

Abstrak: Penggunaan metode seismik gelombang konversi dalam usaha eksplorasi hidrokarbon mengalami peningkatan yang cukup signifikan. Sejak penggunaan seismik konvensional yang memanfaatkan refleksi gelombang P tidak cukup baik dalam memberikan hasil yang akurat pada daerah dengan struktur geologi yang kompleks dan seringkali menghasilkan respon brightspot semu. Prinsipnya adalah gelom- bang datang $\mathrm{P}$ yang menjalar ke bawah permukaan akan mengalami refleksi serta konversi menjadi gelombang $\mathrm{P}$ dan SV pada suatu batas lapisan. Dengan memanfaatkan receiver multikomponen, gelombang kompresi $\mathrm{P}$ dapat direkam pada komponen vertikal dan gelombang geser $\mathrm{S}$ direkam pada komponen horisontal. Pada penelitian ini dibangun sebuah model sintetik dengan reservoir gas dangkal dan di bawahnya terdapat intrusi garam. Tujuan penelitian ini adalah menganalisis respon anomali akibat keberadaan gas dangkal dan pengaruhnya terhadap kualitas refleksi gelombang PP dan PS di bawah zona gas. Untuk mencapai tujuan tersebut, dilakukan pengolahan data vertikal dan data horisontal. Pada pengolahan data horisontal digunakan nilai gamma function $\left(V_{p} / V_{s}\right)$ yang optimum agar menghasilkan citra yang lebih baik dan reliable. Penampang stack menunjukkan respon anomali gas yang didapat pada data konvensional tidak terlihat pada data converted-wave dan intrusi garam dibawah zona gas tercitrakan lebih baik pada data converted-wave dibandingkan dengan data kovensional diakibatkan pengaruh hamburan dan atenuasi oleh kolom gas. Selanjutnya dilakukan analisis model respon AVO data komponen vertikal (PP) dan data komponen horisontal (PS) dalam mengkarakterisasi gas. Kurva model AVO hasil pemrosesan data komponen vertikal (PP) menunjukkan kesesuaian dengan model keberadaan gas yang mana dalam model merupakan anomali AVO kelas 1, dengan intercept positif dan gradient negatif. Hal sebaliknya ditunjukkan oleh hasil pemrosesan data komponen horisontal (PS).

Kata kunci: AVO, respon anomali gas, converted-wave, intrusi garam

\section{PENDAHULUAN}

Sampai saat ini metode yang umum digunakan untuk eksplorasi hidrokarbon adalah seismik refleksi gelombang P. Dikarenakan gelombang kompresi memiliki rasio sinyal terhadap bising yang tinggi, berpropagasi lebih cepat di semua lingkungan dan dapat dihasilkan dari bermacam jenis sumber [Stewart dkk., 1996]. Namun gelombang P memiliki 


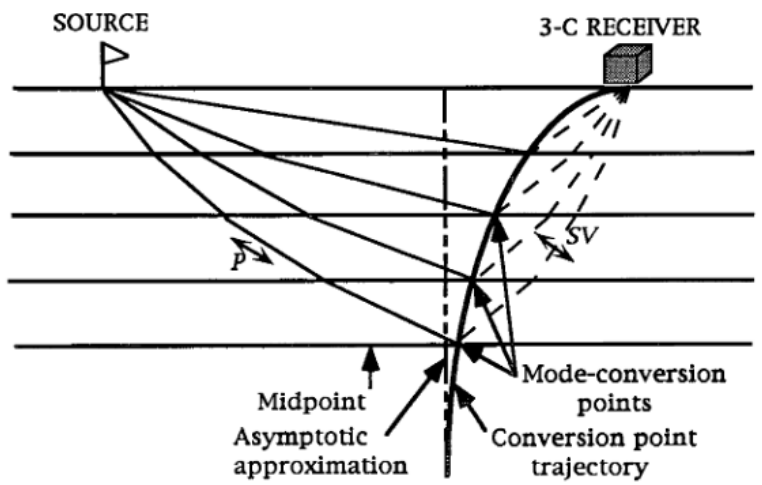

Gambar 1. Diagram skematik converted-wave raypath dan asymptotic conversion point. [Schafer, 1992]

kelemahan dalam memberikan hasil yang cukup baik pada daerah yang kompleks secara geologi dan seismik.

Dengan menggunakan pita frekuensi yang sama, gelombang S akan memiliki panjang gelombang yang lebih pendek. Sehingga akan menghasilkan resolusi vertikal yang lebih tinggi dibandingkan dengan resolusi gelombang P. Namun sulit untuk mendapatkan sumber yang mampu menghasilkan gelombang $\mathrm{S}$ dan gelombang $\mathrm{S}$ kurang mampu berpropagasi untuk kedalaman yang cukup besar akibat efek absorpsi lapisan.

Seiring dengan perkembangan teknologi dan peningkatan kompleksitas obyek dalam survei hidrokarbon, ditemukan suatu metode baru yang dikenal dengan converted-wave seismic exploration. Metode ini mempunyai cara kerja yaitu melakukan perekaman terhadap gelombang S pada komponen horisontal yang berasal dari konversi gelombang datang $\mathrm{P}$. Pada survei ini digunakan receiver multikomponen yang mampu merekam sinyal seismik pada komponen vertikal maupun horisontal.

Respon brightspot atau anomali keberadaan gas yang dihasilkan dari survei seismik konvensional masih memiliki ambiguitas, apakah brightspot disebabkan oleh kandungan fluida misalnya gas atau akibat dari perubahan litologi misalnya batubara. Baik gas maupun batubara akan menghasilkan fenomena brightspot pada penampang seismik konvensional. Namun berbeda halnya dengan penampang seismik converted-wave yang sensitif terhadap rock saturant, sehingga pada penampang seismik converted-wave ambiguitas brightspot dapat dipecahkan. Selain itu biasanya pada penampang seismik konvesional daerah dibawah zona gas tidak dapat teresolusi dengan baik akibat dari atenuasi. Namun converted-wave mampu meresolusi daerah di bawah gas dengan lebih baik.

\section{TEORI DASAR}

\subsection{Metode Converted-wave}

Metode eksplorasi seismik converted-wave prinsipnya adalah menggunakan energi gelombang $\mathrm{P}$ yang berpropagasi kebawah permukaan dan mengalami refleksi ke atas sebagai gelombang $\mathrm{S}$ dari titik penetrasi terdalamnya [Stewart, 2004]. Perekaman converted wave menggunakan receiver

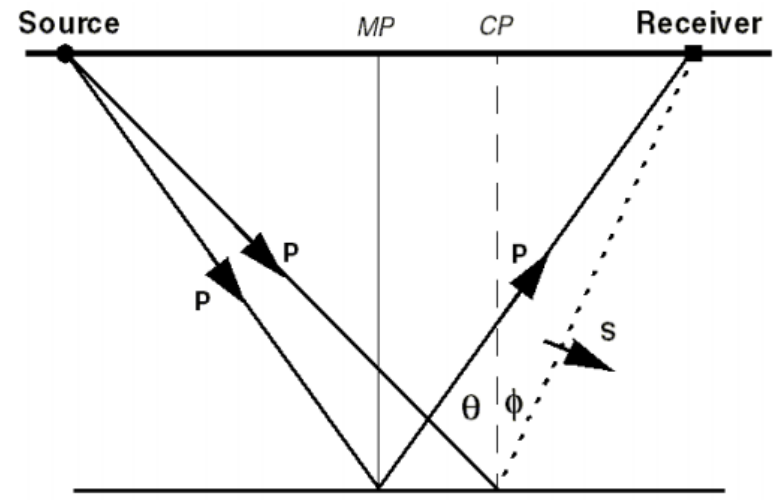

Gambar 2. Titik konversi gelombang PP dan PS [Stewart dkk., 1999]

multikomponen yang mampu merekam komponen vertikal maupun horisontal.

Komponen vertikal terdiri dari komponen gelombang kompresi $\mathrm{P}$ yang merupakan hasil refleksi dari gelombang datang P. Sedangkan komponen horisontal terdiri dari komponen gelombang geser SV yang merupakan hasil refleksi gelombang datang $\mathrm{P}$ dari batas lapisan yang memiliki kontras impedansi elastik.

\subsection{Common Conversion Point (CCP)}

CCP merupakan titik pantul tempat terjadi konversi dari gelombang $\mathrm{P}$ menjadi gelombang $\mathrm{S}$ atau sebaliknya [Sheriff, 2002]. Pada dasarnya sudut datang gelombang $P$ akan lebih besar daripada sudut refleksi gelombang S, dikarenakan gelombang $\mathrm{P}$ berpropagasi lebih cepat daripada gelombang S. Hal ini selaras dengan pernyataan hukum Snell.

Menurut Tessmer dan Behle [1988], persamaan untuk titik pantul $P-S$ converted wave dapat dihitung sebagai:

$$
X_{c}=\frac{X \gamma}{1+\gamma}
$$

Dari persamaan diatas $X_{c}$ merupakan jarak horisontal titik konversi dari source dalam satuan meter, $\gamma$ merupakan rasio $V_{p} / V_{s}$, dan $\mathrm{X}$ merupakan jarak offset dari source ke receiver dalam satuan meter.

\subsection{Depth Variant Stack}

Nilai fold CDP akan digantikan dengan nilai fold ACP yang tergantung pada rata-rata rasio $\mathrm{Vp} / \mathrm{Vs}$ [Lu dan Hall, 2003]. Nilai estimasi $\mathrm{Vp} / \mathrm{Vs}$ awal ditentukan dengan melihat diagram ACP Fold yang menghasilkan fold paling optimal dan stabil.

Depth variant stack merupakan proses memvariasikan $\mathrm{Vp} /$ Vs yang berbeda untuk setiap kedalaman lapisan yang berbeda. Dengan menentukan estimasi nilai $\mathrm{Vp} / \mathrm{Vs}$ untuk setiap reflektor akan menghasikan peningkatan kontinuitas lateral dan penampang stack yang lebih baik dan reliable.

Persamaan matematis berikut merupakan cara untuk mengestimasi fungsi gamma atau rasio $\mathrm{Vp} / \mathrm{Vs}$ pada setiap 


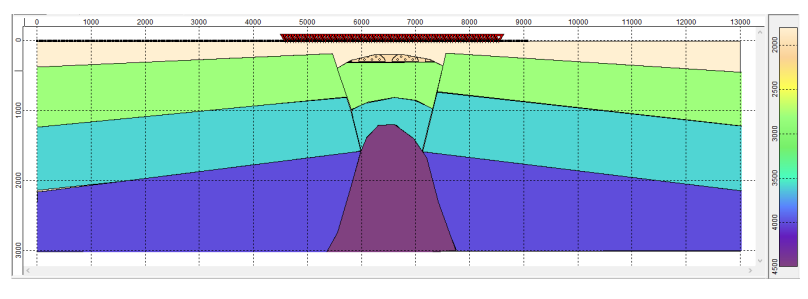

Gambar 3. Model sintetik 2D

Tabel 1. Parameter fisis model sintetik 2D

\begin{tabular}{|c|c|c|c|}
\hline Color & $V_{p}(\mathrm{~m} / \mathrm{s})$ & Vs $(\mathrm{m} / \mathrm{s})$ & Density $\left(\mathrm{kg} / \mathrm{m}^{3}\right)$ \\
\hline & 1800 & 1050 & 1994 \\
\hline & 2800 & 1200 & 2200 \\
\hline & 3600 & 1520 & 2290 \\
\hline & 4000 & 2000 & 2300 \\
\hline & 4500 & 2250 & 2425 \\
\hline & 2010 & 1315 & 2014 \\
\hline
\end{tabular}

reflektor,

$$
\frac{V_{p}}{V_{s}}=\frac{2 T_{p} s}{T_{p} p}-1
$$

Dimana Vp merupakan nilai kecepatan gelombang $\mathrm{P}$, Vs merupakan nilai kecepatan gelombang S, Tps merupakan two-way-time suatu reflektor pada penampang PS stack, dan Tpp adalah two-way-time suatu reflektor pada penampang PP stack

\subsection{Analisis AVO}

Amplitude versus offset merupakan salah satu atribut seismik yang digunakan untuk mengkarakterisasi jenis reservoir. Fenomena ini terjadi karena sudut kedatangan yang berbeda-beda sehingga menghasilkan nilai reflektivitas yang berbeda. Analisis dan inversi AVO simultan PP dan PS meningkatkan estimasi properti batuan dengan menggabungkan beberapa atribut untuk mendapatkan kontras fraksional kecepatan gelombang $\mathrm{P}$ dan $\mathrm{S}$, densitas, dan membedakan antara reservoir dengan litologi non-produktif Sun dan Innanen [2014].

Aki dan Richards [1980] mengenalkan persamaan untuk melakukan aproksimasi nilai reflektivitas gelombang $\mathrm{P}$ ke $\mathrm{P}$ (Rpp) dan converted wave (Rps), yakni:

$$
\frac{V_{p}}{V_{s}}=\frac{2 T_{p} s}{T_{p} p}-1
$$

Dimana Rpp merupakan nilai reflektivitas gelombang $\mathrm{P}$ ke $\mathrm{P}, \mathrm{Rps}$ adalah nilai reflektivitas gelombang $\mathrm{P}$ ke $\mathrm{S}, \theta$ merupakan sudut datang gelombang $\mathrm{P}, \varphi$ merupakan sudut pantul gelombang $\mathrm{S}, \alpha$ merupakan nilai kecepatan gelombang $\mathrm{P}, \beta$ merupakan nilai kecepatan gelombang $\mathrm{S}$, dan $\rho$ adalah densitas.

\section{DATA DAN PENGOLAHAN DATA}

Pemodelan full waveform kedepan dalam penelitian ini diaplikasikan untuk model geologi terdiri dari beberapa lapisan
Tabel 2. Konfigurasi penembakan model sintetik

\begin{tabular}{|c|c|}
\hline konfigurasi & Symmetrical split spread \\
\hline jumlah shot point & 80 \\
\hline source wavelet & Ricker, $15 \mathrm{~Hz}$ \\
\hline spasi shot point & $50 \mathrm{~m}$ \\
\hline jumlah receiver & 182 \\
\hline spasi receiver & $50 \mathrm{~m}$ \\
\hline near offset & $25 \mathrm{~m}$ \\
\hline far offset & $4525 \mathrm{~m}$ \\
\hline
\end{tabular}

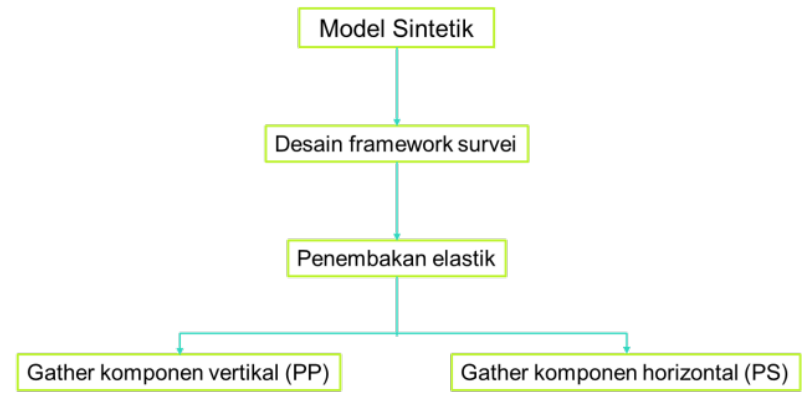

Gambar 4. Diagram alir pemodelan fullwaveform kedepan model sintetik 2D

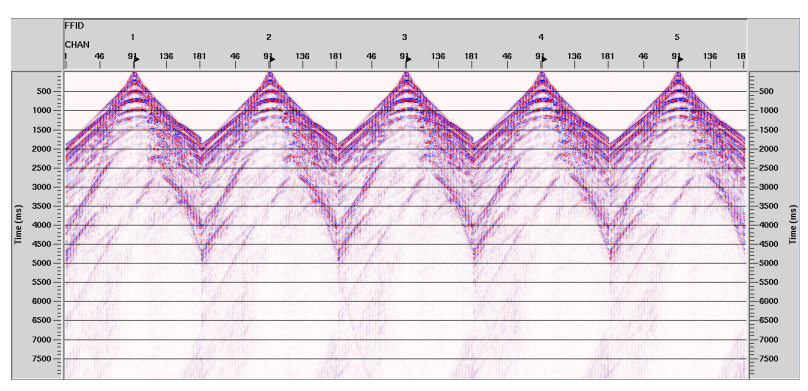

Gambar 5. Shot gather komponen vertikal (PP)

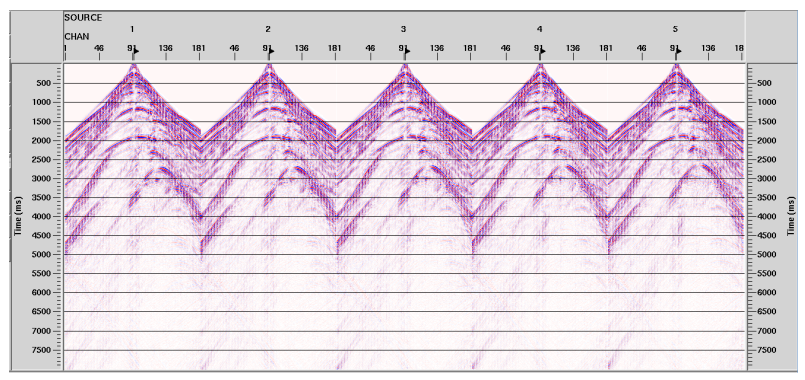

Gambar 6. Shot gather komponen horisontal (PS)

batu pasir, lempung, lempung pasiran, gas dangkal dan intrusi garam. Detail parameter dan konfigurasi penembakan bisa dilihat pada tabel 1 dan tabel 2. Berikut merupakan diagram alir pemodelan kedepan dari model sintetik 2D untuk mendapatkan data seismik sintetik PP dan PS convertedwave:

Pengolahan data dilakukan pada kedua komponen vertikal PP dan horisontal PS converted-wave. Namun sebelum 


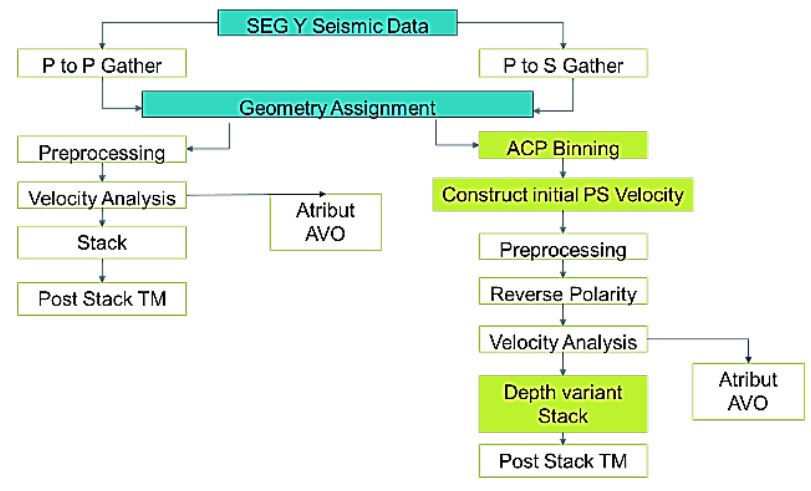

Gambar 7. Diagram alir pengolahan data seismik sintetik PP dan PS converted-wave
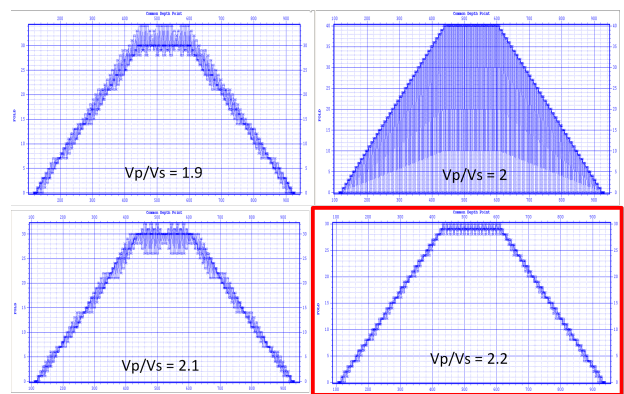

Gambar 8. Diagram ACP folds dengan variasi nilai Vp/Vs. Nilai $\mathrm{Vp} / \mathrm{Vs}$ (kotak merah) merupakan nilai yang optimum untuk digunakan dalam studi ini

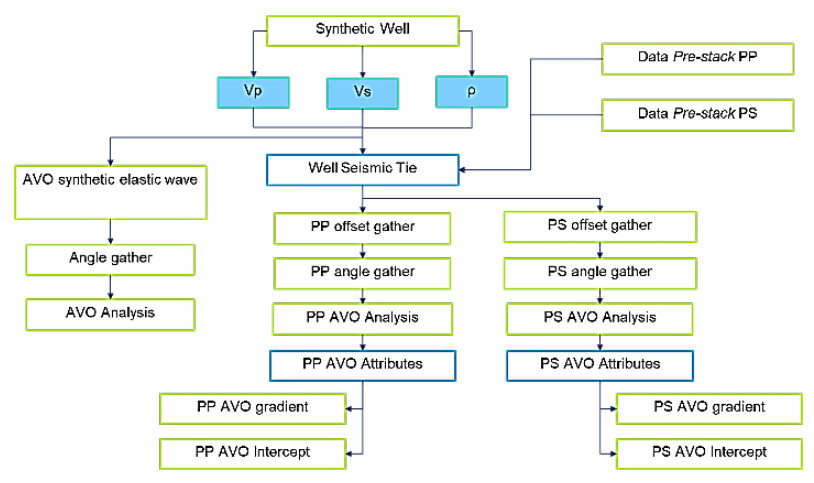

Gambar 9. Diagram alir analisis AVO

mengolah data PS converted-wave, data PP harus diolah terlebih dahulu sampai mendapatkan nilai kecepatan RMS gelombang $\mathrm{P}$ dari data PP. Berikut adalah alur kerja yang dilakukan pada penelitian ini:

Parameter yang paling penting dalam ACP binning adalah nilai rasio Vp/Vs. Dilakukan percobaan nilai Vp/Vs yang berbeda-beda. Nilai yang berbeda-beda menghasilkan diagram ACP fold yang berbeda-beda. Setelah memvariasikan nilai $\mathrm{Vp} / \mathrm{Vs}$, dipilih satu nilai yang terbaik sesuai dengan diagram ACP fold yang paling optimal dan stabil yakni 2.2 pada penelitian ini.

Data pre-stack NMO gather pada CDP 521 data PP dan PS yang melewati zona gas akan diproses lebih lan-

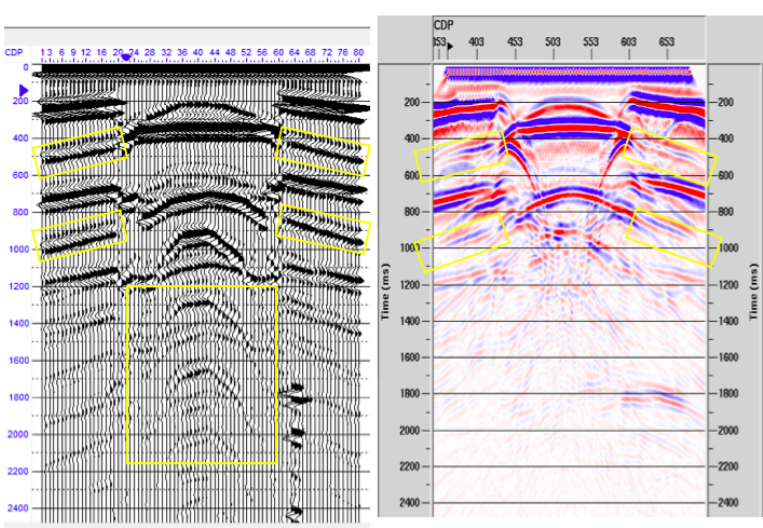

Gambar 10. Normal incidence stack (kiri) dan penampang stack PP (kanan). Reflektor pada kotak kuning diinterpretasi sebagai multiple

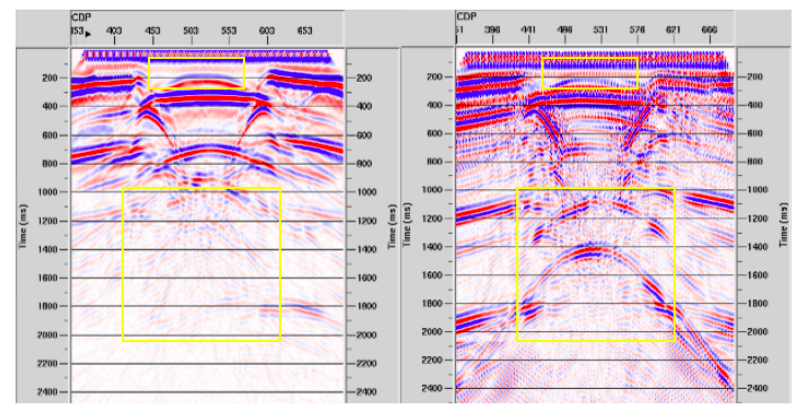

Gambar 11. Penampang stack PP (kiri) dan PS (kanan). Perbedaan respon yang ditandai dengan kotak kuning
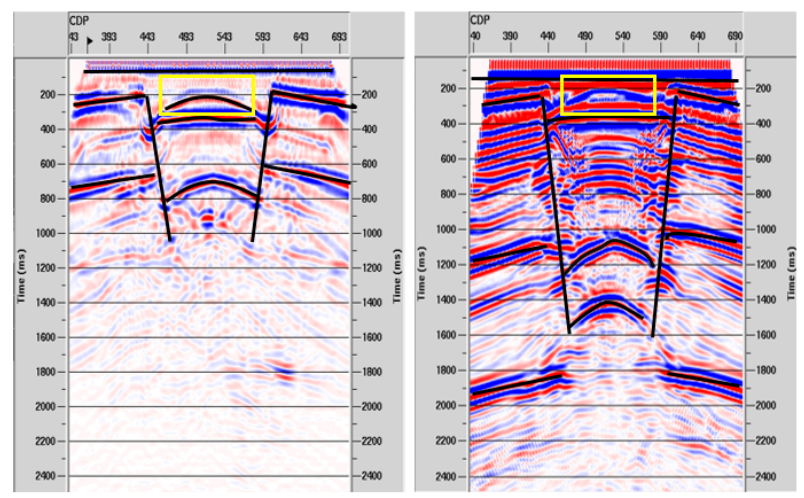

Gambar 12. Interpretasi horizon penampang migrasi PP (kiri) dan PS (kanan)

jut untuk analisis AVO. Tahapan ini bertujuan untuk mengkarakteriasi jenis reservoir gas dari perubahan amplitudo pada zona gas terhadap offset atau angle. 

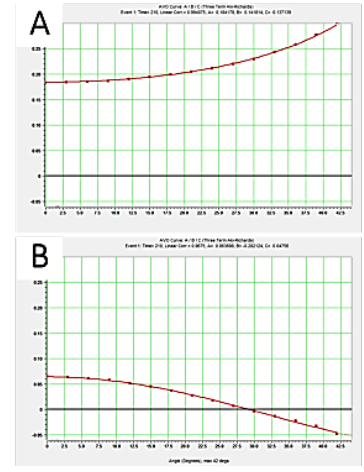

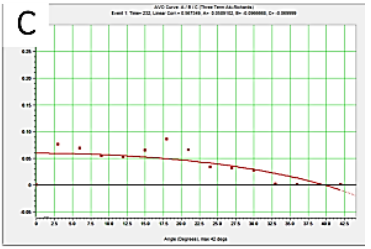

Keterangan gambar:

A.kurva AVO PP sumuran(brine) B.kurva AVO PP sumuran(gas) C.kurva AVO PP seismik
Gambar 13. Respon AVO model sumuran untuk kasus brine (A) dan gas (B) dan respon AVO seismik komponen vertikal (PP) CDP 521
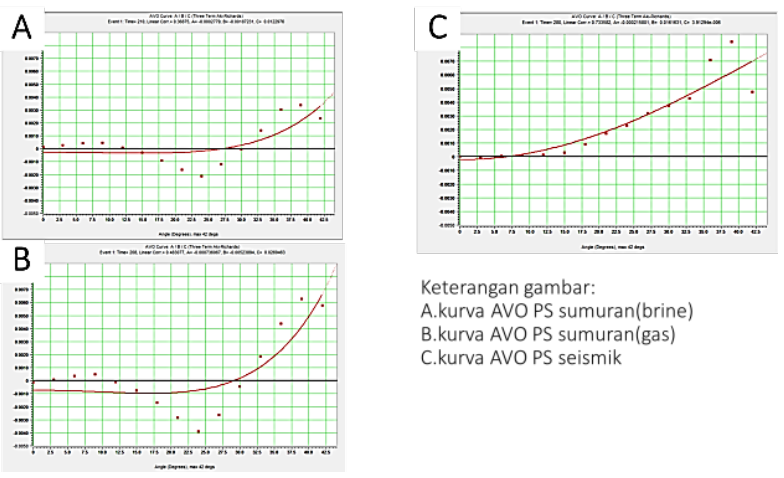

Keterangan gambar:

A.kurva AVO PS sumuran(brine B.kurva AVO PS sumuran(gas) C.kurva AVO PS seismik
Gambar 14. Respon AVO model sumuran untuk kasus brine (A) dan gas (B) dan respon AVO sesimik komponen horisontal (PS) CDP 521
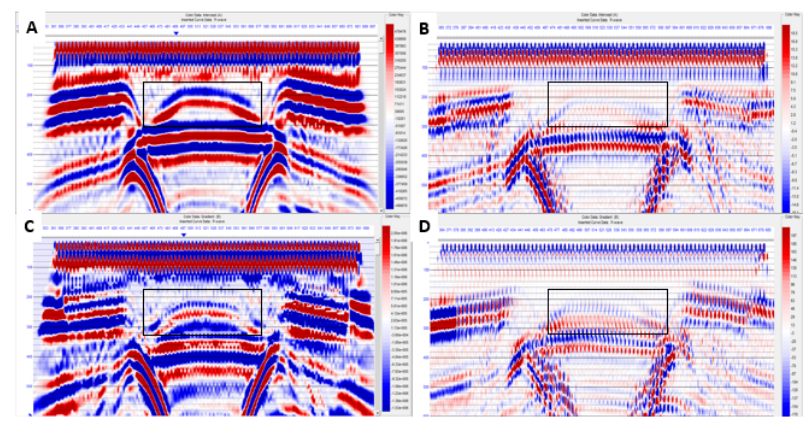

Gambar 15. Penampang intercept data PP (A) dan PS (B) dan penampang gradient data PP (C) dan PS (D)

\section{DISKUSI DAN PEMBAHASAN}

\subsection{Interpretasi Horizon}

Digunakan informasi tambahan sebagai guidance yaitu model normal incidence section yang merupakan hasil perekaman refleksi gelombang $\mathrm{P}$ pada zero offset. Model normal incidence dibandingkan dengan model bawah permukaan untuk membedakan reflektor primer dengan multiple. Dengan identifikasi awal multiple, interpretasi horizon pada penampang stack PP dan PS menjadi lebih pasti atau unique.

Dapat dilihat bahwa pada penampang stack PP, masih mengandung banyak multiple. Namun pada penampang migrasi PP sudah cukup bersih dari keberadaan multiple. Perlu diperhatikan bahwa pada penampang PS terjadi delay waktu dari penampang PS dan model normal incidence section. Hal ini disebabkan karena gelombang refleksi S membutuhkan waktu propagasi yang lebih lama dibandingkan gelombang P. Sehingga reflektor yang sama berada pada two-way-time yang berbeda pada penampang PP dan PS. Penampang stack PS dan penampang migrasi PS juga masih mengandung banyak multiple residu gelombang P. Hal ini diakibatkan karena perekaman converted-wave sangat didominasi oleh energi gelombang $\mathrm{P}$.

Terdapat beberapa perbedaan lainnya pada image vertikal (PP) dan horisontal (PS) yakni pada komponen vertikal terdapat respon anomali keberadaan gas (brightspot) dengan jelas pada daerah yang diperkirakan adalah top gas. Namun respon anomali gas tersebut tidak terlihat pada penampang converted-wave. Komponen vertikal PP tidak mampu mendeteksi keberadaan intrusi garam dengan cukup baik. Namun pada komponen horisontal PS intrusi garam tercitrakan dengan baik. Hal ini diakibatkan karena pada komponen vertikal, energi gelombang mengalami hamburan dan atenuasi saat melewati kolom gas. Sehingga daerah dibawah zona gas tidak dapat tercitrakan dengan baik. Berbeda halnya dengan gelombang S yang tidak sensitif terhadap fluida.

\subsection{Analisis AVO}

Analisis AVO dilakukan dengan membandingkan model AVO sumuran yang dibangun dari persamaan gelombang elastik menggunakan data single well dengan model AVO dari data seismik PP dan PS NMO gather dimana pada penulisan ini diambil contoh adalah CDP 521. Kedua data baik CDP model sumuran maupun seismik hasil pemrosesan dikonversi dari offset gather menjadi angle gather. AVO model sumuran berfungsi sebagai quality control pada saat melakukan analisis AVO dengan data seismik.

Kurva AVO data seismik vertikal PP CDP 521 menunjukkan ciri AVO kelas 1. Ketidakteraturan NMO gather pada zona gas diakibatkan offset yang kurang lebar (wide angle) untuk kasus zona gas yang terlalu dangkal sehingga terpengaruh efek stretching sangat dominan. Analisis data hasil pemrosesan didukung secara koheren dengan data analisis AVO model sumuran yang juga menunjukkan ciriciri AVO kelas 1. AVO kelas 1 merupakan anomali dari high impedance gas. Namun kurva AVO seismik PS convertedwave CDP 521 tidak menunjukkan anomali. Hal ini juga didukung dari analisis AVO sintetik converted-wave PS yang tidak menujukkan anomali.

Penampang intercept dan gradient juga menunjukkan anomali yang jelas pada data PP namun tidak terlihat pada data PS. Top gas ditunjukkan oleh intercept positif berupa warna merah yang kuat dan menerus dan gradient negatif berupa warna biru yang kuat dan menerus pada data PP. Namun pada data PS daerah tersebut intercept dan gradient tidak terlihat. 


\section{$24 \quad$ Viony dan Triyoso (2018)}

\section{KESIMPULAN}

Berdasarkan analisis yang telah dilakukan terhadap hasil penelitian ini, maka dapat disimpulkan, 1. Akibat pengaruh keberadaan gas dangkal, reflektor dibawah zona gas khususnya daerah intrusi garam tidak tercitrakan dan teresolusikan pada penampang vertikal $\mathrm{PP}$, namun tercitrakan dengan baik pada penampang PS. Hal ini disebabkan karena pengaruh energi gelombang $\mathrm{P}$ yang mengalami hamburan dan atenuasi saat melewati daerah gas. 2. Respon AVO hasil pemrosesan data cukup konsisten dengan model sumuran (dalam kasus ini berupa gas dangkal) pada penampang vertikal P-P, namun tidak terlihat pada penampang convertedwave PS dikarenakan gelombang $\mathrm{S}$ tidak sensitif terhadap rock saturant. 3. Dari penampang intercept-gradient, hasil pemrosesan data seismik terdapat anomali berupa intercept positif dan gradient negatif yang kuat dan menerus pada komponen PP, namun tidak terlihat pada komponen PS.

\section{DAFTAR PUSTAKA}

Aki, K., dan Richards, P. G. 1980. Quantitative Seismology: Theory and Methods, 1, W.H. Freeman and Co.

Hardage B.A., DeAngelo M.V., Murray P.E., SAVO D. 2011. Multicomponent seismic technology. Society of Exploration Geophysicists, Tulsa.

Kristiansen, P. 2000. 4 years experience with $4 C$ seismic: what we have learned: Presented at the SEG/EAGE Summer Research Workshop, Boise, Idaho.

Lu, H. dan Hall, K. 2003. Tutorial: Converted wave (2D PS) processing. CREWES Research Report, 15.

Nahm, J. W., dan Duhon, M. P., 2003. Interpretation and practical applications of 4C-3D, East Cameron gas fields, Gulf of Mexico. The Leading Edge, 22, 300 - 309

Rutherford, S.R. dan Williams, R.H. 1989. Amplitudeversus-Offset Variations in Gas Sands. Geophysics, 54, 680-688.

Schafer, A. W. 1992. A comparison of converted-wave binning methods using a synthetic model of the Highwood Structure, Alberta. CREWES Research Report, 4.

Sheriff, R. E. 2002. Encyclopedic dictionary of applied geophysics, Society of Exploration Geophysicists, Tulsa.

Stewart, R. R., Gaiser, J. E., dan Lawton, D. C. 1996. P$S$ Seismic Exploration: A mid term overview. CREWES Research Report 8.

Stewart, R. R., Gaiser, J.E., Brown, J. dan Lawton, D. C. 1999, Converted-wave seismic exploration: a tutorial. CREWES Research Report, 11.

Stewart, R. R. 2004, Converted-wave seismic exporation: An update. CREWES Research Report, 16.

Sun, J. dan Innanen, K. 2014. A review of converted wave AVO analysis. CREWES Research Report, 26.

Tessmer, G. dan Behle, A., 1988. Common reflection point data-stacking technique for converted wave, Geophysical Prospecting, 36, $671-688$.

Triyoso, W., Oktariena, M., dan Sinaga, E., 2017. Full waveform modelling for subsurface characterization with converted-wave seismic reflection, IOP Conference Series: Earth and Environtmental Science, 6. 